\title{
Timing of the reproductive cycle of waved whelk, Buccinum undatum, on the U.S. Mid-Atlantic Bight
}

\author{
Sarah Borsetti ${ }^{*}$, Daphne Munroe ${ }^{1}$, David Rudders ${ }^{2}$ and Jui-Han Chang ${ }^{3}$
}

\begin{abstract}
Development of the unmanaged waved whelk (Buccinum undatum) fishery on the Mid-Atlantic continental shelf of the United States has initiated investigation into fisheries-related biological and population attributes of the species in this region. Maturation and reproduction timing vary by location for this species and are likely linked to bottom water temperature. This study examined the seasonal fluctuations in relevant body metrics and gonadosomatic index in relation to bottom temperature to assess the timing of the reproductive cycle of the $B$. undatum population in the southern-most extent of this species' range in the Atlantic. To characterize variation over the maturation schedule, nine locations in the Mid-Atlantic Bight (MAB) were sampled five times between January 2017 and September 2017. Maturity was assessed macroscopically, with morphological methods, and via gonadosomatic indices. Male behavioral maturity estimates, based on a penis length to shell length index $\left(P L_{50}\right)$, were compared to estimates made using other methods for assessing maturity to test the efficacy of this commonly used ratio. Mature whelk were found in all months and peak reproductive activity was observed in spring and early summer. This timing suggests that ideal sampling to visually identify maturity to estimate size of maturity would be late winter or early spring. Unique oceanographic dynamics in the MAB, such as strong seasonal stratification results in large changes in annual bottom temperature which appears to be closely linked to the reproductive cycle in this region. Our data suggest that $B$. undatum in the MAB experience spawning and development at $\sim 7-8{ }^{\circ} \mathrm{C}$; temperatures warmer than Canadian populations and cooler than some UK conspecifics. To our knowledge, this is the first study to document the annual reproductive cycle of waved whelk in the United States.
\end{abstract}

Keywords: Buccinum undatum, Reproduction, Maturity estimates, Fisheries, Temperature, Gonadosomatic index

\section{Introduction}

The waved or common whelk (Buccinum undatum) is a cold-water subtidal marine gastropod, distributed through the North Atlantic and adjoining seas. Throughout its distribution, it is commercially important and has been harvested in Europe and Canada for both bait and human consumption for decades [1-4]. New fisheries for this species have recently been developed in several

*Correspondence: sarahbor@hsrl.rutgers.edu

${ }^{1}$ Haskin Shellfish Research Laboratory, Rutgers University, 6959 Miller Ave., Port Norris, NJ 08349, USA

Full list of author information is available at the end of the article countries, including the United States [5, 6], specifically the Mid-Atlantic region of the Northeast U.S. Shelf (NE Shelf). As is now well documented, assessing and monitoring waved whelk has proven to be difficult due to spatially variable life-history parameters $[3,5,7-9]$ and its ability to form localized subpopulations [10-13], both of which make this species vulnerable to overexploitation if fishery managers assume equivalency across the range of the animal [3, 5, 7-9]. To inform future management in the Mid-Atlantic region of the US, it is critical that appropriate data is collected during early fisheries development to understand population structure and spatially variable biology [14].

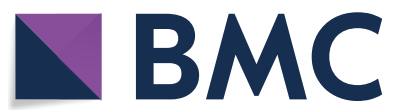

c) The Author(s) 2020. This article is licensed under a Creative Commons Attribution 4.0 International License, which permits use, sharing, adaptation, distribution and reproduction in any medium or format, as long as you give appropriate credit to the original author(s) and the source, provide a link to the Creative Commons licence, and indicate if changes were made. The images or other third party material in this article are included in the article's Creative Commons licence, unless indicated otherwise in a credit line to the material. If material is not included in the article's Creative Commons licence and your intended use is not permitted by statutory regulation or exceeds the permitted use, you will need to obtain permission directly from the copyright holder. To view a copy of this licence, visit http://creativeco mmons.org/licenses/by/4.0/. 
Buccinum undatum is gonochoric, its reproductive cycle has been well documented across most of its range with considerable variability in spawning timing [2, 1518]. Whelk display distinct breeding periods with clear seasonal development of the gonads, the onset of spawning is signaled by a noticeable increase in gonad size [9]. Females aggregate during spawning and lay small spherical egg capsules that are deposited on hard surfaces such as rock or shell [15]. Larval development occurs inside the egg capsules and depending on location and temperature, egg masses take between 10 weeks to 9 months to develop into crawl-away juveniles $[15,17,19]$.

Whelk gonads undergo seasonal reproductive cycles $[16,17]$ which have proven to be useful indicators to determine reproductive timing through the species' range. Studies in the eastern Atlantic have shown that at the southern extent of whelk distribution, egg-laying primarily occurs through the fall and winter months when water temperatures are trending downward to their annual minimum $\left(\sim 4-10{ }^{\circ} \mathrm{C}\right)[2,9,17,20]$. Whelk populations from west Iceland and Sweden, the northern end of the species distribution, follow a similar pattern as European populations with egg-laying occurring from fall to winter [21-23]. In contrast, in the upper northwest Atlantic, Gulf of St. Lawrence, Canada, egg-laying was observed in spring and summer directly after annual minimum bottom temperatures gradually increased to $\sim 2-3^{\circ} \mathrm{C}[15]$.

Across the distribution of $B$. undatum, a broad thermal range is experienced by different populations with annual temperatures ranging from below $0{ }^{\circ} \mathrm{C}$ to above $22{ }^{\circ} \mathrm{C}$ [19]. Egg-laying and development do not occur over this entire temperature range and have been observed to be limited to temperatures between 2 and $10{ }^{\circ} \mathrm{C}$ [20] with thermal reproductive tolerance varying between populations. This variation in development timing has been linked to differences in temperature during development, where small increases in temperature, specifically at the lower end of the thermal range, result in shorter periods of development timing [19]. Juvenile whelk in the UK emerge from their egg capsules 3 to 5 months after egg-laying, while in Canada this takes place after 5 to 8 months $[15,17]$. Martel et al. $[15,16]$ suggest that overall variation in timing of the reproductive cycle in $B$. undatum between European waters and those of Eastern Canada may be due to water temperatures, with European recorded winter water temperatures higher than the average summer temperature reported in the Gulf of St. Lawrence. However, Laptikhovsky [24] suggested the switch in reproductive timing in the northwest Atlantic may be an adaptation to protect newly emerged juveniles from seasonal predatory pressure from their major predator, Leptasterias polaris, which is non-existent in European waters.

Seasonal patterns in gonad condition can be identified by fluctuations in gonadosomatic indices (GSI), gonad indices, and macroscopic assessments [9, 16-18, 21]. For males, behavioral maturity, the ratio of penis length to shell length, has been used regularly to confirm male maturity $[3,5,25,26]$, yet recent work has questioned the validity of this maturity classification method due to incorrect assessment of visually immature animals $[9,21]$. To examine the efficacy of penis length as an indicator of male maturity, iterative search procedure have been used to examine this morphological relationship $[9,21,27,28]$. The seasonality variation in gonad condition results in fluctuations in maturity estimates throughout the year. Both Hollyman [21] and Haig et al. [9] highlight the need for sampling and maturity assessments to occur before the spawning season, when individuals display maximum gonad differentiation, as these maturity estimates may be used to inform fisheries management regulations, and if estimates are misspecified due to inappropriate sampling timing, a population could be inadequately protected.

The description of annual reproductive timing has yet to be performed on southern populations on the NE shelf, along the Mid-Atlantic Bight (MAB), particularly in waters of New Jersey where fishery development is occurring. Recent expansion of the unmanaged waved whelk fishery on the Mid-Atlantic continental shelf has initiated investigation into fisheries-related biological and population attributes of the species in this unique region. This region experiences intense stratification as surface water temperatures rise in response to surface heating while deeper waters are influenced by cold waters from the north [29]. Stratification begins in the spring, and by early summer forms one of the world's sharpest thermoclines with temperatures range from $\sim 30^{\circ}$ to $8{ }^{\circ} \mathrm{C}$ in just a few meters [30]. A band of cold bottom water extends over this region and persists until early fall when the passage of storms reduces the stratification [31-37]. Additionally, this region along the NE shelf has experienced the largest change in thermal conditions observed in temperate waters off North America [38-40]. Studies show that invertebrate communities of the NE shelf are likely vulnerable to the effects of climate change. Particularly sensitive are those animals like the waved whelk that are less mobile, dependent upon calcium carbonate shells, and associated with specific habitats [41, 42].

Due to stratification and a seasonally persistent band of cold bottom water (cold pool) in the MAB, large fluctuations in annual bottom temperature may result in unique reproductive timing for $B$. undatum. Systematic observations of the timing of reproductive events in the Mid-Atlantic region would provide 
a better understanding of whelk population dynamics. In addition to understanding the relationship between temperature and reproductive timing, it is important to comprehend the reproductive cycles of exploited stocks, such as waved whelk, as it has significant implications for this species' vulnerability to exploitation. This study tests the validity of multiple metrics for estimating male maturity and examines fluctuations in various body metrics and GSI in relation to observed and modelling bottom temperature. The collected information allows determination of the annual pattern of reproductive events and suggests recommended timing for sampling whelk in the MAB to most accurately estimate maturity. Finally, this study culminates with a description of the reproductive cycle of $B$. undatum for the southern-most population in the range of this species in the Northwest Atlantic Ocean. To our knowledge, this is the first study to document the annual reproductive cycle of waved whelk in the Mid-Atlantic.

\section{Methods}

\section{Sample collection}

Samples were collected in the MAB in partnership with Virginia Institute of Marine Science (VIMS) sea scallop targeted fishery sampling. Sampling occurred at the same nine stations approximately every 2 months from January 2017 through September 2017 onboard commercial scallop vessels (Fig. 1). These sampling events targeted Atlantic sea scallops (Placopecten magellanicus), although $B$. undatum were incidentally caught. Borsetti et al. [5] show that whelk and sea scallops commonly co-occur throughout the domain of this region. At each station, a dredge with a $2.4 \mathrm{~m}$ wide frame equipped with $5.1 \mathrm{~cm}$ rings, $10.2 \mathrm{~cm}$ twine top, and a $3.8 \mathrm{~cm}$ mesh liner was towed for $15 \mathrm{~min}$ at a speed of approximately 3.8-4.0 knots [43, 44]. No estimate of whelk catch efficiency for this survey gear is available; however, Borsetti et al. [5] calculated an average abundance for this region of 0.0012 whelk $/ \mathrm{m}^{2}$. Whelk collected by dredge ranged from 21.9 to $87 \mathrm{~mm}$ total shell length (TSL). Distance towed, depth,

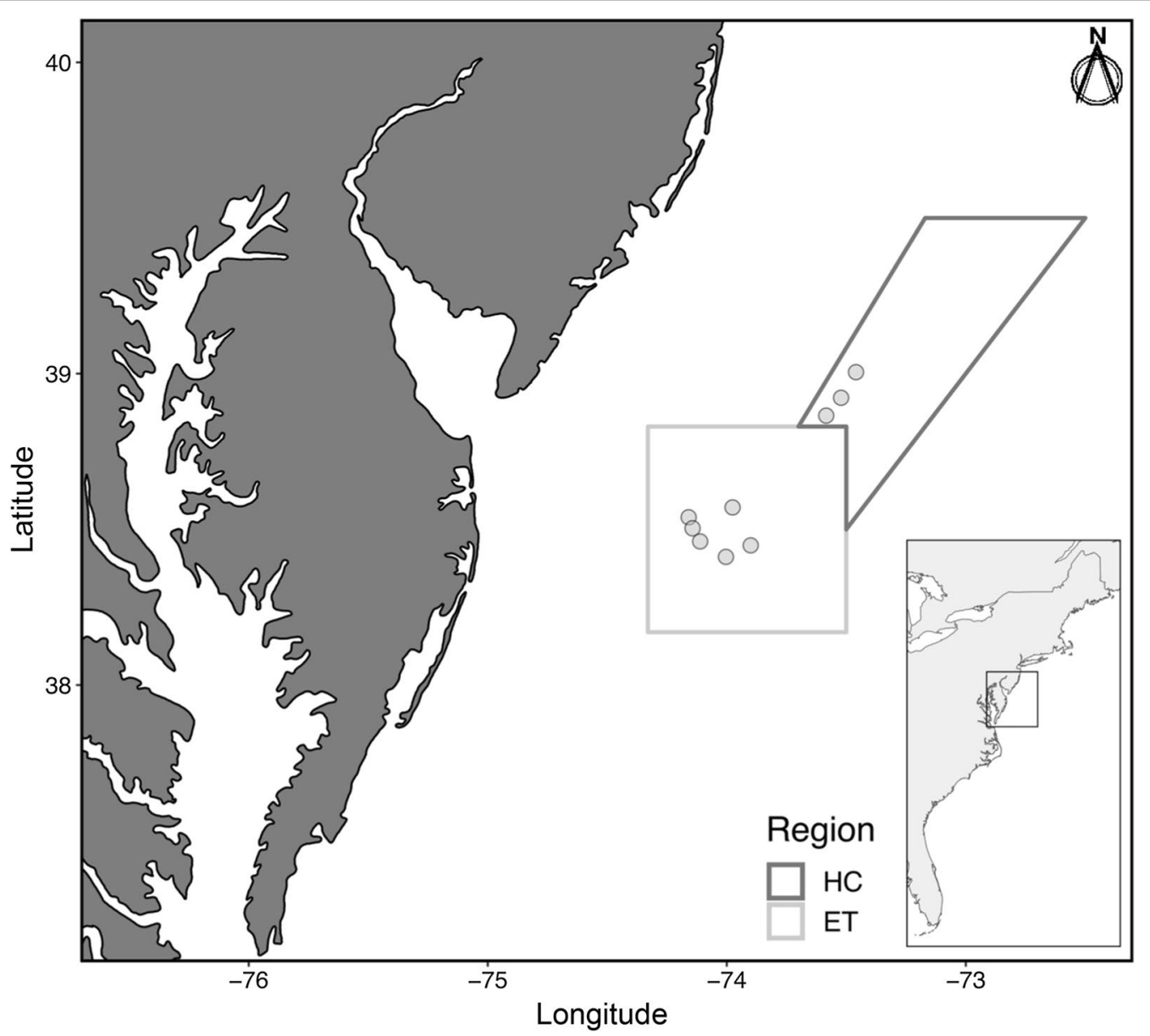

Fig. 1 Map of the MAB region, showing location of the nine sites sampled in 2017. Map also includes the boundaries of the two scallop access areas in the MAB (HC: Hudson Canyon; ET: Elephant Trunk). Locations of each dredge sampling station shown with gray circles 
and bottom water temperature were recorded at each station. At each sampling station, all whelk were retained, labelled with station information, and frozen for subsequent analysis.

\section{Temperature}

\section{Observed}

A Star-Oddi tilt sensor (a device that records time, angle of inclination, temperature, depth) was mounted to the dredge frame and was used to determine dredge bottom contact time. A shipboard GPS unit logged vessel location every $2 \mathrm{~s}$ and was used to estimate the activity of the sampling gear in time and space [43]. For the purposes of this analysis, temperature measurements from the sensor were integrated to the GPS data and only measurements taken when the dredge was in contact with the seafloor were retained. For each sampling trip, bottom temperatures across all 9 sampling sites were pooled to calculate an average bottom temperature for a given sampling event. The observed bottom water temperatures were compared to model-generated temperatures (described in the following section) to characterize the thermal conditions experienced by whelk in this region.

\section{Modelled}

A 35-year (1980-2015) hindcast of ocean temperature is available as output from the Regional Ocean Modeling System (ROMS) model [45]. This modelling temperature time series was bias-corrected using observed bottom water temperatures [46] measured during the National Marine Fisheries Service/Northeast Fisheries Science Center assessment surveys, conducted mainly in spring, summer, and fall of each year. These fisheries surveys, typically occur during the annual minimum and maximum bottom temperatures. Bias correction substantively improved the fit of ROMS model temperature output relative to observations. The bias-corrected hindcast temperature time series provided continuous oceanographic conditions that were used to resolve seasonal minimum and maximum bottom temperatures over the study area.
These simulated data formed the basis for the generation of a 10-year, monthly climatology from 2005 to 2015 for the southern MAB region. This climatology was then used to examine the relationship between temperature and the reproductive cycle of whelk in the MAB.

\section{Maturity}

Whelk retained during dredge surveys were thawed before processing. Each specimen was extracted following methods detailed in Borsetti et al. [5]. Sex was recorded for each individual and was determined by the presence or absence of a penis. Whelk display distinct seasonal breeding periods and therefore gonads of mature whelk are variable throughout the year. The first measure of maturity, a macroscopic assessment of gonadal maturity, was used to determine functional maturity $[9,27,47]$. A maturity stage; immature, developing, or mature (Table 1), was assigned based on development of the gonad [9, 47, 48]. From the macroscopic assessment of maturity, each whelk was assigned a binary factor of functional maturity (mature/developing $=1$; immature $=0$ ).

Monthly population estimates of functional maturity were calculated using a logistic regression model and defined as the size at which $50 \%$ of the population is mature $\left(\mathrm{L}_{50}\right)[49,50]$. Whelk with an atypical gonad as a result of parasite infestation were excluded from the analysis of size of sexual maturity [51]. More information about size of maturity calculation can be found in Borsetti et al. [5]. Maturity curves were fit using a base $\mathrm{R}$ code (adapted from Harry [52]), which is available online and has also been utilized in a number of studies for this species (i.e. [5, 9, 21, 53]). Confidence intervals were added by bootstrapping the generalized linear model (10,000 runs). Significance was tested by comparing the amount of deviance explained relative to the null model using Chi squared tests. Monthly $\mathrm{L}_{50}$ estimates were then compared to a previously predicted size of maturity estimate from the same region [5].

Table 1 Maturity stage assessment definitions for male and female whelk using visual assessment methods. Modified from Haig et al. [9]

\begin{tabular}{llc}
\hline Stage & Male & Female \\
\hline Immature (I) & $\begin{array}{c}\text { No obvious differentiation between digestive gland and } \\
\text { gonad (testis). Vas deferens invisible }\end{array}$ & $\begin{array}{c}\text { No obvious differentiation between digestive gland and } \\
\text { gonad (ovary) }\end{array}$ \\
Developing (II) & $\begin{array}{l}\text { Some visible differentiation between the anterior edge of } \\
\text { digestive gland and gonad (testis), possibly a visible vas } \\
\text { deferens }\end{array}$ & $\begin{array}{c}\text { Some visible differentiation between the anterior edge of } \\
\text { digestive gland and gonad (ovary), possibly a visible pallial } \\
\text { oviduct }\end{array}$ \\
$\begin{array}{l}\text { Full differentiation between digestive gland and gonad } \\
\text { (testis) obvious, visible vas deferens in males }\end{array}$ & $\begin{array}{c}\text { Fully differentiation between digestive gland and gonad } \\
\text { (ovary), visible enlarged pallial oviduct }\end{array}$ \\
\hline
\end{tabular}


Similarly, males were given a binary factor of behavioral maturity to indicate maturity stage based on a penis length to shell length index $\left(\mathrm{PL}_{50}\right)$. Males with a penis length greater than or equal to half of their shell length (PL: SL) were considered behaviorally mature $[3,4,54]$. To examine the efficacy of penis length as an indicator of male maturity, an iterative search procedure was used to examine this morphological relationship using the following linear model:

$$
\mathrm{SL}=\mathrm{PL} * \mathrm{I}(\mathrm{x}<\mathrm{c})+\mathrm{x} * \mathrm{I}(\mathrm{x}>\mathrm{c})
$$

where * is the main effects and interactions for both variable. This model searches for deviations from the linear model and estimates an inflection (or breakpoint) (c) between shell length (SL) and penis length (PL) by finding a point where the residual standard error is minimized $[9,55]$. Inflection points were calculated for each sampling event and for data aggregated from all MAB samples and indicate the fluctuations in male behavioral maturity estimates throughout the year.

Fluctuations in female GSI, the ratio between the gonadal weight and the total eviscerated weight, were examined to identify peak periods of gonad development. The gonadal weight comprised of the ovary and pallial oviduct (composed of the seminal receptacle, albumen gland, capsule gland, and bursa) which were dissected and a combined weight was recorded [3]. The eviscerated weight, total weight minus the gonad and variable digestive gland, was also recorded [16]. Fluctuations in female GSI for developing, mature, and both developing and mature were examined and compared using a repeated measures ANOVA and a Tukey's post hoc test.

Additionally, similar to other studies, the relationship between the mature female gonad (pallial oviduct and ovary) and digestive gland were examined [16, 18]. To streamline sample processing, the pallial oviduct and ovary (POO) weights were combined during dissection. This combined weight was used because studies have shown that weight of these two female structures had the same trend throughout the reproductive season $[16,18]$. The average POO and digestive gland were compared for mature females over the sampling period. Seasonal changes in the size of the female gonad and digestive gland were compared using a repeated measures ANOVA and a Tukey's post hoc test.

\section{Results}

\section{Sample Collection}

A total of 602 whelk were caught over five sampling trips from January 2017 to September 2017. During

\begin{tabular}{|c|c|c|c|c|}
\hline Sample date & Males & Females & $\begin{array}{l}\text { Observed } \\
\text { temperature }\end{array}$ & $\begin{array}{l}\text { Modelled } \\
\text { temperature }\end{array}$ \\
\hline January 2017 & 32 & 49 & 10.2 & 10.4 \\
\hline March 2017 & 118 & 138 & 8.1 & 6.4 \\
\hline May 2017 & 63 & 89 & 7.0 & 9.2 \\
\hline July 2017 & 13 & 24 & - & 8.7 \\
\hline September 2017 & 34 & 42 & 9.4 & 12.1 \\
\hline
\end{tabular}

Bottom temperature from observed bottom temperatures (dredge sensor) and modelled hindcast temperatures. Dashes indicate that data was not available

each sampling trip, the number of whelk collected varied by month and sex (Table 2).

\section{Temperature \\ Observed}

Monthly average bottom temperatures ranged from a minimum of $7{ }^{\circ} \mathrm{C}$ in May 2017 (Table 2) to a maximum of $16.6^{\circ} \mathrm{C}$ in November of 2016 (Fig. 2a), representing a seasonal change of almost $10^{\circ} \mathrm{C}$ through the year (Table 2). The temperature sensor was not mounted to the dredge during the month of July and therefore no bottom temperatures are available for that sampling date.

\section{Modelled}

The average monthly temperature from the model generated 10-year hindcast climatology ranged from a minimum of $6.4{ }^{\circ} \mathrm{C}$ in March 2017 (Table 2) to a maximum of $15.8{ }^{\circ} \mathrm{C}$ in November 2016 (Fig. 2a). Both observed and modelled bottom temperatures depict similar annual trends in temperature. Temperature minimums are observed in the spring (March-May) and temperature maximums in the fall and winter months (OctoberDecember) (Fig. 2a). Similarities among observed and modelling bottom temperatures suggest that this study occurred during a year in which bottom temperatures were within the expected temperature range for the $M A B$ region.

\section{Maturity}

The proportion of whelk in each reproductive stage varied over time. Mature whelk were found during each sampling with the highest percentage in May for males and September for females (Fig. 2b, d). There was a large increase in the proportion of immature males and females in the month of March.

The estimated functional $\mathrm{L}_{50}$, based on macroscopic assessments, varied for each month sampled due to the seasonality of the whelk breeding cycle which results in 
(See figure on next page.)

Fig. 2 a Average bottom temperature (black line) with 95\% confidence interval (grey band) calculated from 10-year hindcast climatology and average bottom temperature (black diamond) with standard deviation calculated from observed data from each site sampled (white circle) b Proportion of males in each maturity stage (Immature: light gray; Developing: gray; Mature: black). c Comparison of three different male maturity metrics (IP: inflection point, black; $L_{50}$ based on visual assessment of gonads with $95 \%$ confidence interval, grey; $P L_{50}$ shell length: penis length $95 \%$ confidence interval, white). d Proportion of females in each maturity stage (Immature: light gray; Developing: gray; Mature: black). e Female GSI separated by qualitatively assigned maturity stage (Developing: white; Mature: gray; Developing and mature: black) for each month sampled with $95 \%$ confidence interval

fluctuations in gonad development. Maturity at length curves for each month sampled were all significant when tested against the null model (Fig. 3). Gradual slopes for each of the maturity curves indicate maturation occurs over a range of lengths even within a sample. In all months sampled females consistently had a larger $L_{50}$ than males. Functional estimates of maturity range from 57.1-64.2 $\mathrm{mm}$ for females and 54.6-62.5 $\mathrm{mm}$ for males. The female population level $\mathrm{L}_{50}$ is at its largest in January $(64.2 \mathrm{~mm})$ and decreases slightly during the expected egg-laying period (March, $60.9 \mathrm{~mm}$ and May, $63.1 \mathrm{~mm}$ ). By September, after egg-laying is expected to have occurred, the observed $\mathrm{L}_{50}$ is at its smallest $(57.1 \mathrm{~mm})$. Male population level $\mathrm{L}_{50}$ follows an inverse trend to that of females. In January, the males have the lowest observed $\mathrm{L}_{50}(54.6 \mathrm{~mm})$ which steadily increases through the spring and fall and peaks in September $(62.5 \mathrm{~mm})$. Overall $\mathrm{L}_{50}$ estimates for all months sampled is $56.9 \mathrm{~mm}$ for males and $61.6 \mathrm{~mm}$ for females.

Iterative searches found the inflection in the PL: SL relationship to be highest in January $(65.3 \mathrm{~mm})$, steadily decrease during spring and summer (March-58.3 mm, May- $54.1 \mathrm{~mm}$ ), and starting to build again by fall $(61.6 \mathrm{~mm})$ (Fig. 4). The inflection points closely resemble the behavioral $\mathrm{PL}_{50}$ estimates and follows a similar trend (Fig. 2c). $\mathrm{PL}_{50}$ slightly overestimates maturity; however, some of these overestimates still fall within the $95 \%$ CI of behavioral maturity. The $\mathrm{PL}_{50}$ and inflection point calculated for January are highly similar but disagree with the functional maturity estimate by approximately $10 \mathrm{~mm}$. Due to small sample size, the iterative search procedure was unable to be completed for July.

Female GSI varied over the sampling period, particularly among mature females. Mature female average GSI was largest in January and decreased in size significantly by May $(\mathrm{p}=0.05)$, indicating spawning had occurred (Fig. 2e, gray points). For developing females there was an increasing trend in GSI throughout the year, peaking in September. When mature and developing females are pooled, differences between months are no longer significant.

For mature female whelk, there is a clear inverse seasonal pattern between the weight of the female gonad (POO) and digestive gland (Fig. 5). Sampling began in winter with the female POO larger than the digestive gland. By spring the difference in size between these structures decreased. In early summer, the female gonad is significantly reduced in size $(p=0.02)$ and is now smaller than the digestive gland, this trend is observed throughout summer sampling. There is a significant reduction in average size of the female gonad when comparing samples from January to May $(\mathrm{p}=0.05)$. The digestive gland reaches its peak size in late summer. By fall, both the female gonad and digestive gland has decreased in size, resulting in the two structures being comparable weights. No relationship exists between the female gonad (POO) and digestive gland for both immature and developing females.

\section{Discussion}

The reproductive cycle of $B$. undatum in the Mid-Atlantic Bight observed from January 2017 through September 2017 suggests that the principal egg-laying period in this portion of its range is March through May. This period coincides with minimum bottom temperatures in the MAB suggesting that temperature may be driving reproductive timing in this region. This reproductive timeframe is supported by both a morphometric indicator of male maturity and GSI for mature females, which sharply and significantly decreased between March and May, suggesting that egg-laying occurred. Eggs have been observed in benthic samples during the summer months, May through August (pers. obs.), supporting this suggested reproductive timing window. The relationship between the two body-component indices (POO \& digestive gland) demonstrates that mature female gonad mass is reduced by March indicating that some of the population has already spawned and begun to lay eggs.

Determination of sexual stages in this study are based on multiple approaches: macroscopic assessment of gonad, dissection and weighing of gonad, and comparison of penis length $[8,9,18,48]$. Methods for this study were selected because they were more time-efficient and allowed for larger sample sizes, even though they lack some of the precision of other methods (i.e. histological observations). The functional $\mathrm{L}_{50}$ varied by sample for both sexes, yet females consistently had larger maturity estimates in all months. Previous maturity estimates in 


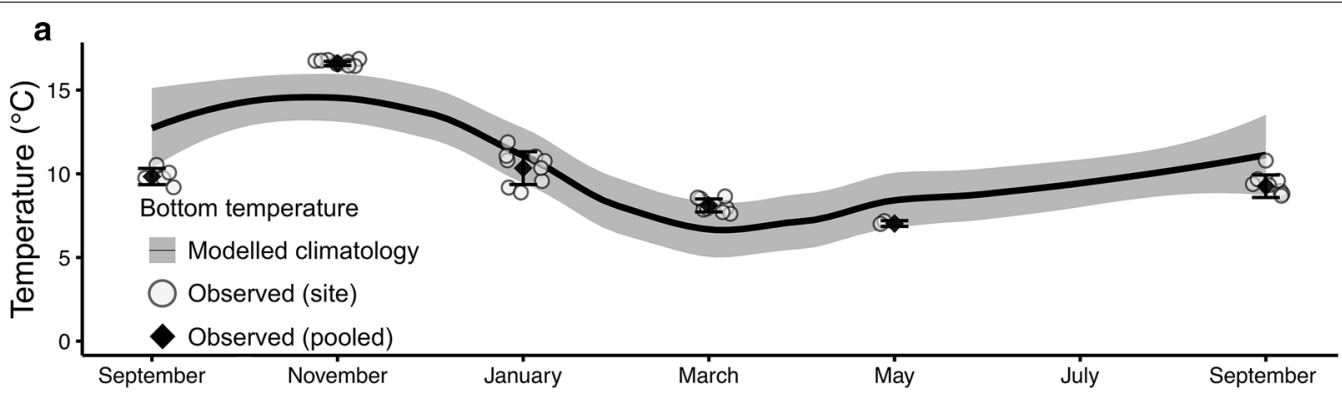

b
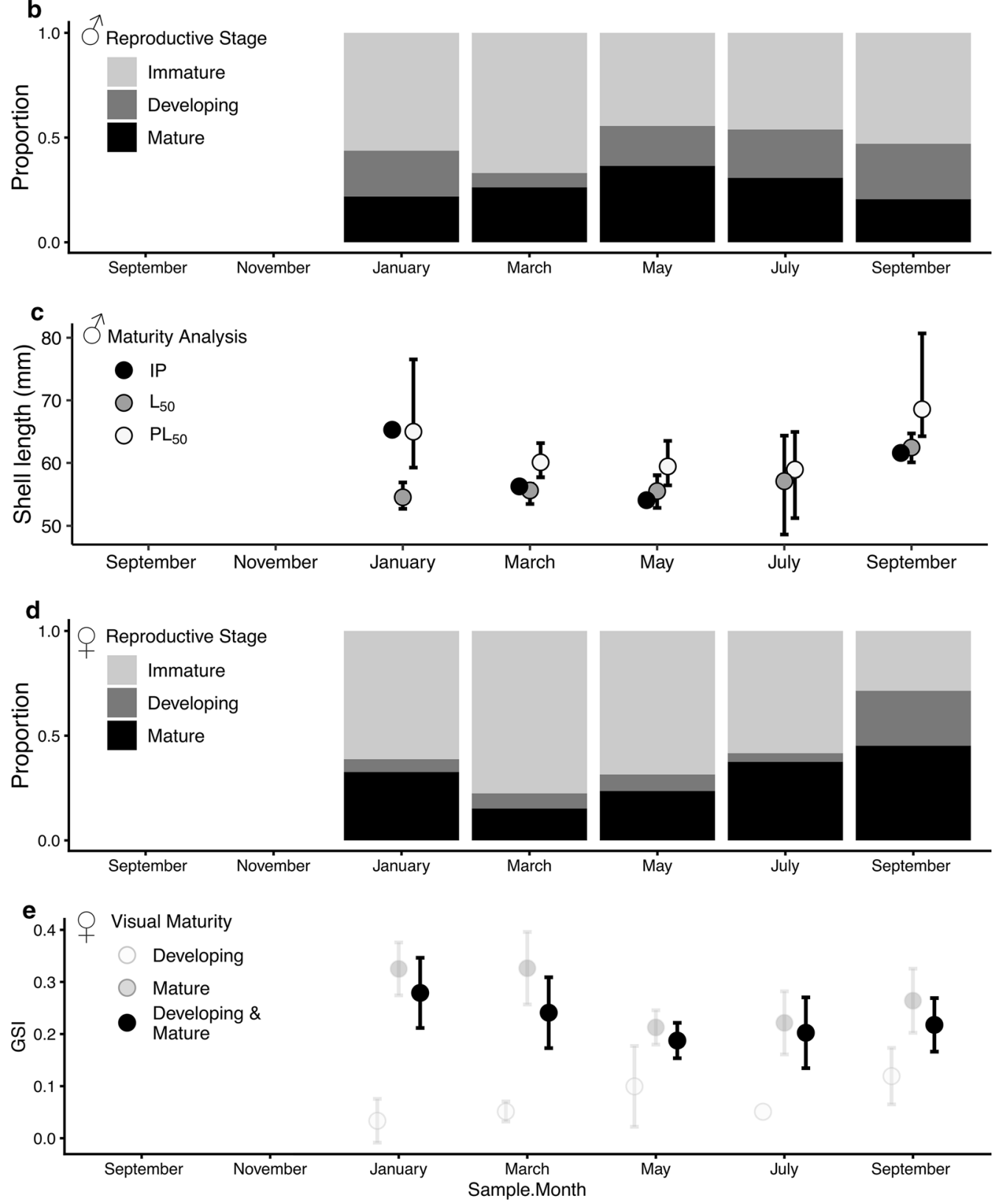


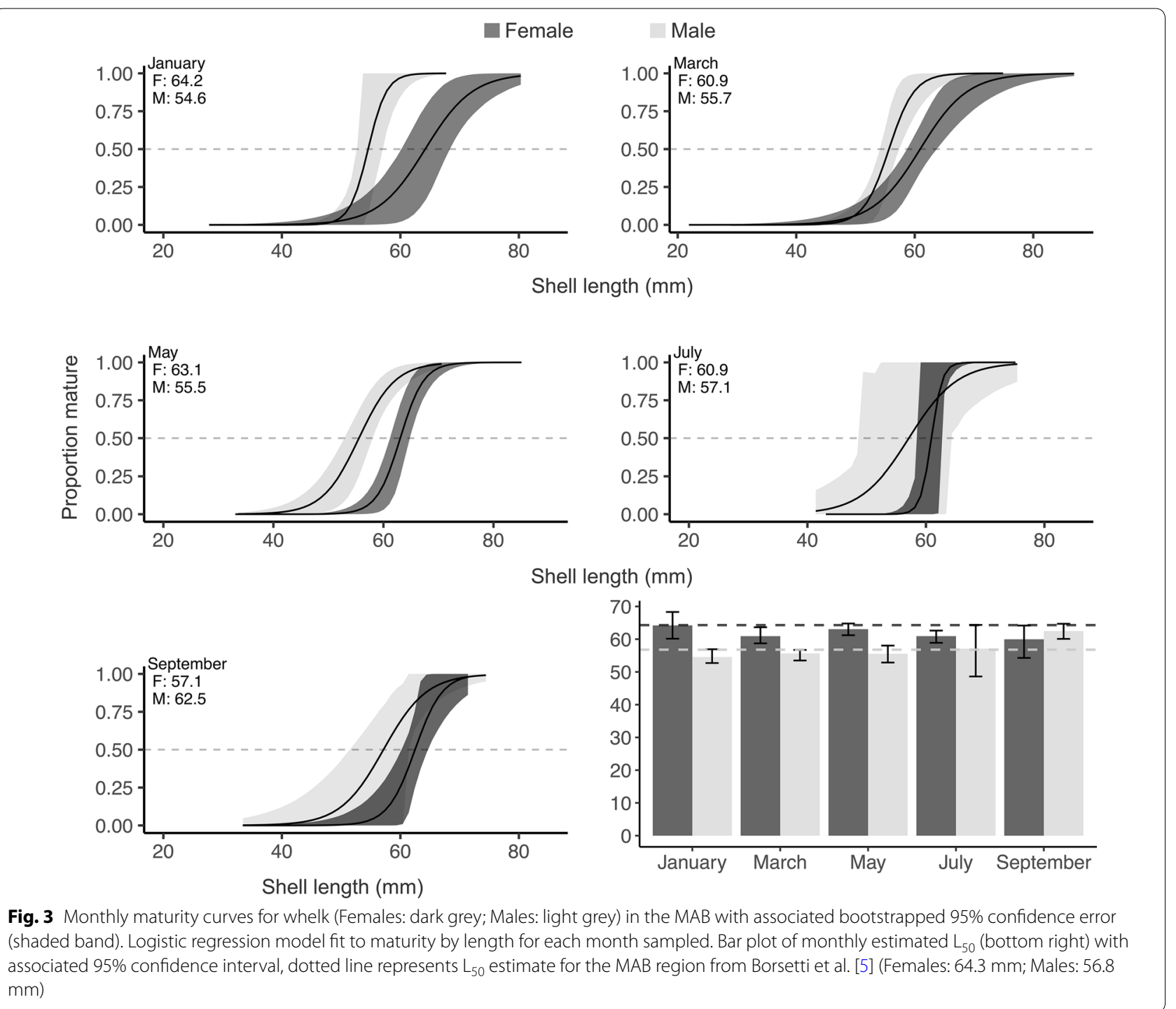

this region used different methods, however, past estimates only slightly overestimate maturity [5] (Fig. 3). In comparison, estimates made in this study may be more conservative due to the inclusion of developing whelk in the mature category (Table 2). Despite differences in methodology, females consistently had larger size of maturity estimates [5]. This trend is not consistent in all assessed populations, some studies have found no differences in size of maturity between sexes [26], while others in heavily fished regions have found males consistently maturing at larger sizes than females $[9,21]$. Female $L_{50}$ increased in January prior to spawning. Similarly, during January and March female whelk had higher GSI values. The $L_{50}$ value progressively decreased throughout the sampling period. Similar seasonal changes in maturity have been observed in Wales $[9,21]$ indicating that increases in $\mathrm{L}_{50}$ coincide with peaks in the seasonal breeding cycle. Male functional maturity based on macroscopic assessment revealed an inverse $\mathrm{L}_{50}$ trend when compared to females. The $\mathrm{L}_{50}$ value progressively increased throughout the sampling period, reaching a maximum in September. Suggesting an inverse relationship between male testis development and ovary development in females. This unusual pattern, first described by Martel et al. [16], was attributed to male's long-term ability to store sperm. Trends in increasing male testis index in both Buccinum undatum [16] and Buccinum isaotakii [56] have been directly correlated with increases in water temperature which was associated with the advancement in spermatogenesis. In this study, the greatest proportion of mature male whelk samples were found in the warmest months, January and September.

Estimates of maturity based on both the iterative search procedure and the male behavioral assessment for all 

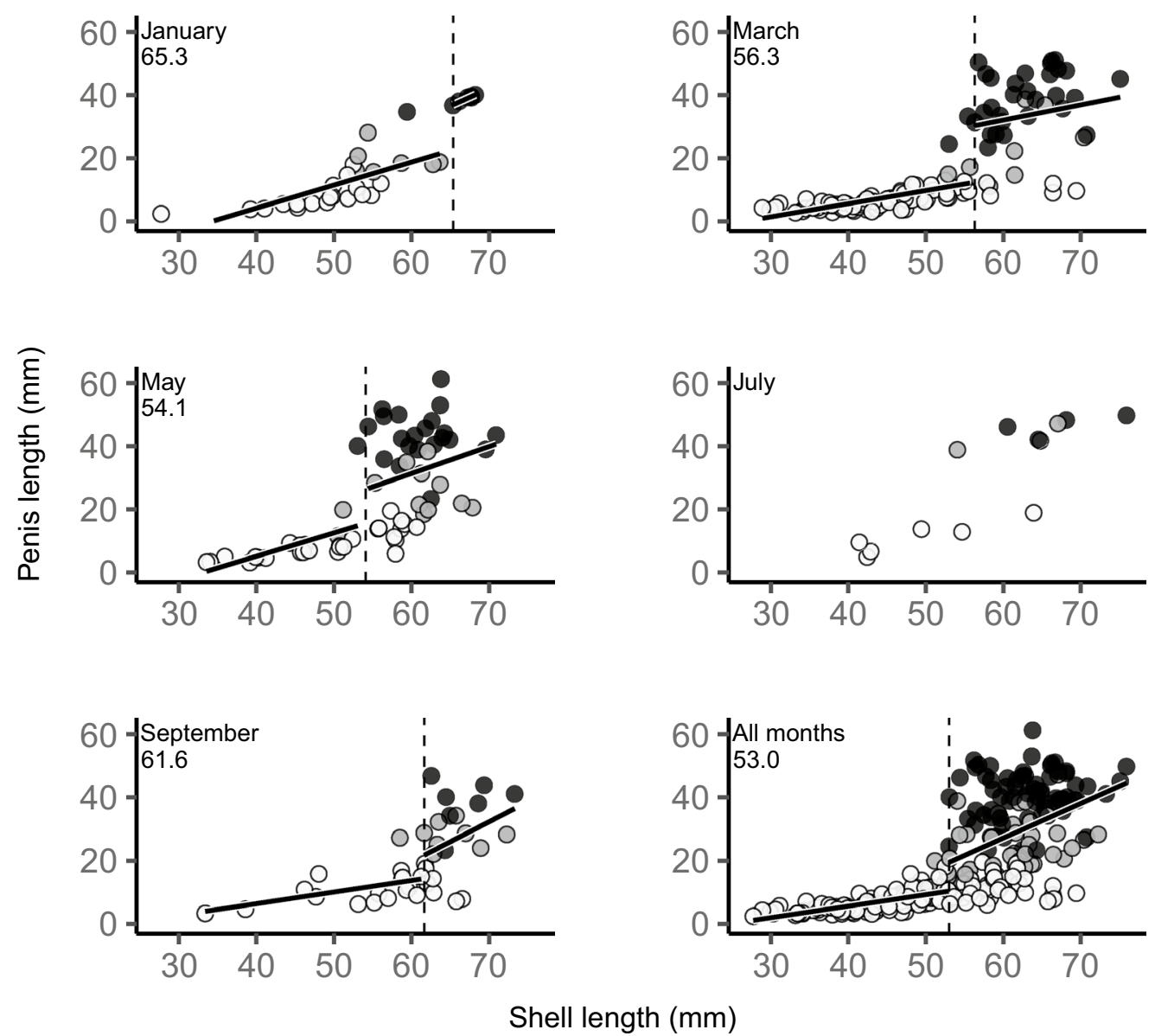

Fig. 4 Inflection point for each month sampled and all months combined indicating allometric growth patterns based on the variance between iterative tests on linear models of penis length $(\mathrm{mm})$ and total shell length $(\mathrm{mm})$ for males. The dotted black line indicates the value for each month with the lowest standard error. Maturity stage, based on macroscopic examination of the gonad are indicated by the color of the points (Immature: white; Developing: gray; Mature: black)

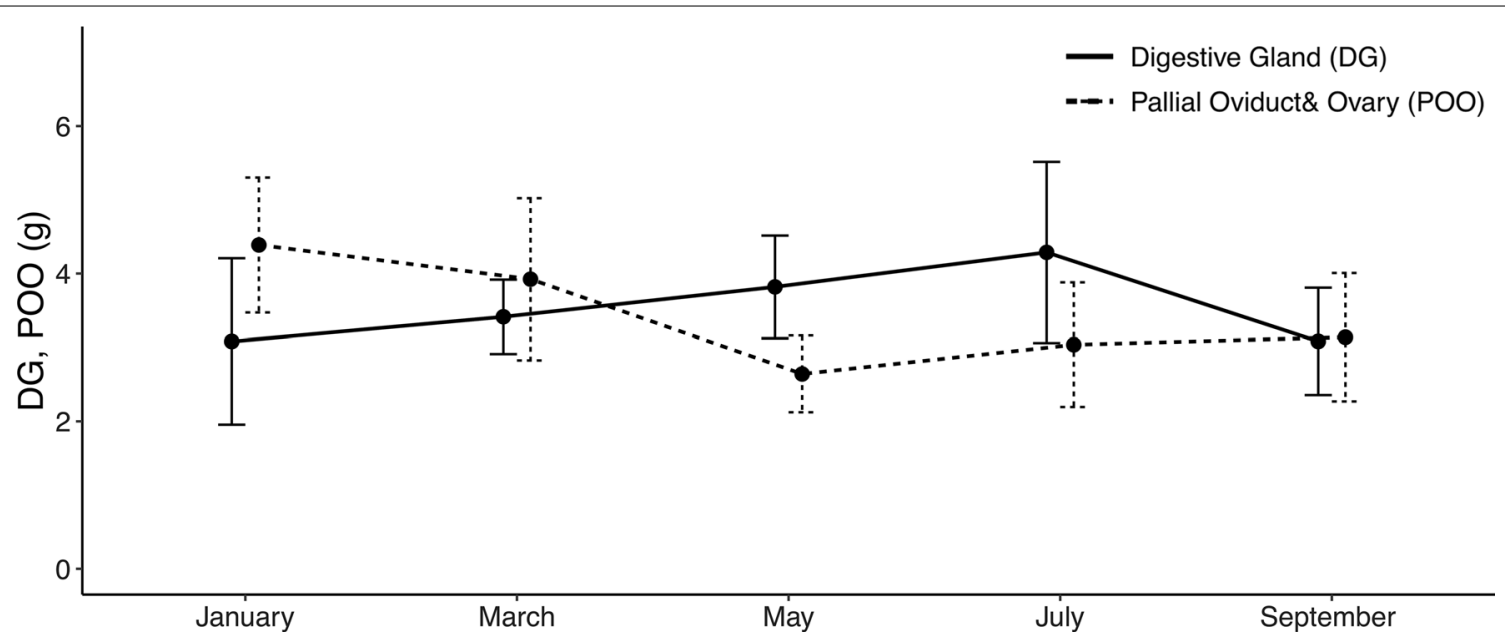

Fig. 5 Average seasonal variation in the weight (grams) of mature female body-component indices of the digestive gland (DG) (solid line) pallial oviduct and ovary (POO) (dotted line) and associated 95\% confidence interval 
months were similar; however, the $\mathrm{PL}_{50}$ estimates slightly overestimate maturity. Conversely, the winter functional maturity $\left(\mathrm{L}_{50}\right)$ appears to be an underestimate perhaps because the $\mathrm{L}_{50}$ curve is based more on developing rather than mature whelk. Despite these differences, behavioral maturity (the penis length to shell length ratio) is a viable method of determining maturity in males in this region, particularly, when gonad differentiation is indistinguishable (i.e. directly after spawning when gonads are spent) $[9,57]$. Some studies have found the maturity estimates made using $\mathrm{PL}_{50}$ closely resemble those made using $\mathrm{L}_{50}$ [26], yet others have found that $\mathrm{PL}_{50}$ slightly [21] or considerably [9] overestimates maturity.

Seasonal fluctuations in $\mathrm{L}_{50}$ have implications on future fisheries management for this species. Minimum landing size, a common fisheries management approach, can be informed by estimated size of sexual maturity. If misspecified, a population could be inadequately protected if $\mathrm{L}_{50}$ is underestimated due to the timing of sampling. Future assessments of the size of sexual maturity should aim to include this seasonal consideration into study design to ensure proper assessment of maturity. Seasonal variation in maturity observed in this and other studies suggest that assigning maturity is more difficult outside of annual reproductive periods [9]. Because of this species' distinct reproductive seasonality, gonads are not equally apparent throughout the year. An ideal time to visually assess gonads is prior to the spawning season when there is the greatest differentiation between the ovary and associated digestive gland. This study suggests that the ideal time is during late winter or early spring in the MAB. If assessing size of maturity during other seasons, it may be useful to incorporate other indicators of maturity to confirm maturity. Replication of this study is recommended to fill sampling gaps during unsampled months and years with bottom temperature anomalies to examine if seasonal patterns are consistent.

Several gastropods reduce feeding during their breeding season, this includes several whelk species, Nucella (Thais) lapillus [58], Nucella lamellosa [59, 60], and Buccinum undatum [2, 16, 61]. During the warm winter months this population appears to be building gonad which coincided with reduced feeding activity and thus a smaller digestive gland. Experimental fishing with baited pots in early December of the previous year in the MAB, a period when bottom temperatures were relatively warm $\left(\sim 15{ }^{\circ} \mathrm{C}\right)$, resulted in extremely low catch (unpublished data, pers. obs.), which may support this hypothesis of reduced feeding during early winter months. Similarly, studies in Ireland show a decrease in catch through the summer months when feeding is at its lowest and temperatures were at their highest $[62,63]$. The inverse cycle observed for mature females between the digestive gland and gonad agrees with other studies $[16,18]$ and further confirms that feeding activity is reduced during the reproductive season. After the primary egg-laying period, which occurs between March and May, the female gonad start to slowly develop again and are similarly sized to the digestive gland by September, suggesting that there was little rest period before renewed ovarian development.

Some studies examining reproductive cycles of this species have used baited pots for sample collection (i.e. $[9,18,64])$. Santarelli and Gros [4] indirectly indicate a link between the reduced feeding and onset of reproduction in the French fishery based on catch per unit effort, which severely decreased from August through October. Other studies have also suggested that whelk are less attracted to baited pots during reproduction [65, 66] which may bias samples collected during this time to non-reproductive members of the population. Feeding activity and catchability in waved whelk may change with reproductive state [65] such that catch from baited pots may result in a biased sample that fails to include maturing females that are building gonad. Dredge catches may provide a better representation of the population [5] and likewise the reproductive cycle over the annual period.

Waved whelk are a boreal species, its temperature tolerance does not favor an energetically costly reproductive period over the summer in Europe [16]. Studies have described populations at the southern end, mainly the UK, of this species' distribution as fall/winter spawners, with eggs being laid as water temperatures cool and reach their annual minima. Populations previously studied in the northwest Atlantic inhabit colder waters and lay eggs spring and summer as water temperatures warm from annual minima $[16,17,67]$ (Fig. 6). Whelk in Breiðafjörður (Iceland) had a similar reproductive season to that of Europe (October-March) but seawater temperature $\left(0-5{ }^{\circ} \mathrm{C}\right)$ during this time were more similar to those experienced by whelk in the Gulf of St. Lawerence $[22,23]$. This suggests that the seasonality of European whelk may be linked to timing of juvenile hatching to allow rapid growth during times when abundant food reserves are present. The population examined in this study represents the southern-most for B. undatum in the northwest Atlantic [5]. Our results suggest that in the MAB egg-laying occurs during the spring and early summer (March-May) slightly earlier than conspecifics to the north. The MAB population is more similar to those in the UK which lay their eggs when the bottom water temperature is at a minimum, rather than during rising temperatures (i.e. Canada). Given the findings from this work, it appears that whelk in the MAB experience spawning and development at warmer temperatures $\left(\sim 7-8{ }^{\circ} \mathrm{C}\right)$ than Canadian populations and cooler than some UK populations. Hatching juveniles likely emerge 


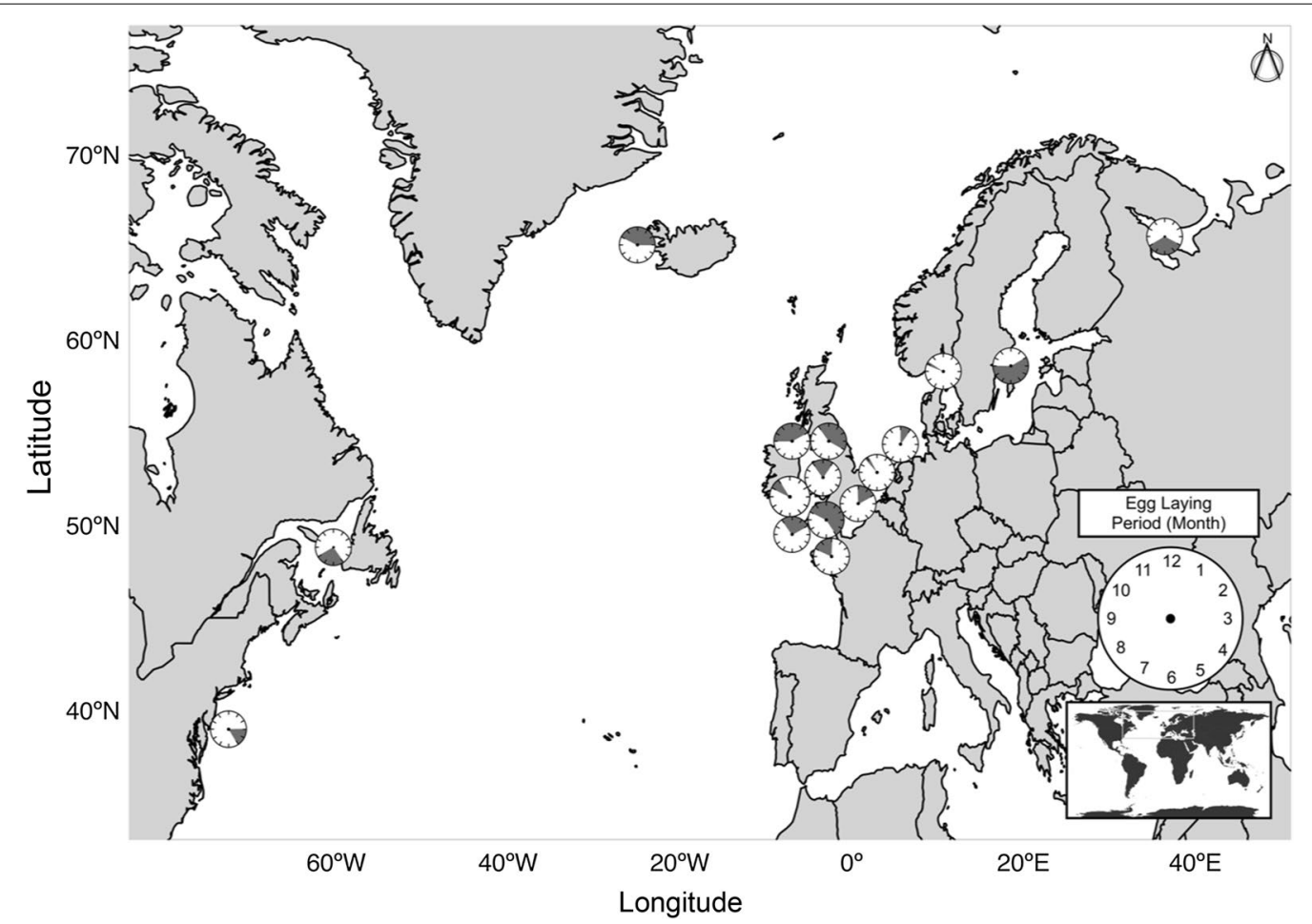

Fig. 6 Egg-laying period obtained from published literature and assessment reports of whelk populations. Approximate location of studies are shown with associated egg-laying period in months are represented with a clock. Shaded numbers on clock correspond to months which egg-laying was observed. [Canada: [15, 16]; France: [64]; Iceland: [22]; Isle of Man: [17, 77]; Netherlands: [78]; Russia: [79]; Sweden: [18, 80]; United Kingdom: $[2,9,20,21,81,82]$; United States: This study]

during warm fall temperatures-a similar pattern to those in the UK, but with an inverse season. The MAB, with its unique bottom temperature dynamics as a result of strong stratification and a sustained cold pool, could be creating an annual reproductive period that appears offset compared to $B$. undatum populations previously examined elsewhere.

The Northeast U.S. Shelf Ecosystem is one of the most rapidly warming marine systems in the world with a sea surface temperature trend (from 2004 to 2012) of increasing $\sim 0.2{ }^{\circ} \mathrm{C}$ a year [68]. Should this trend continue, these temperatures may fall outside of the thermal tolerance for waved whelk and could have a significant impact on survival and development. Studies have shown that warming conditions can lead to lower recruitment, deleterious physiological effects, suboptimal growth, impacts on development and reduction in survival which can affect fisheries productivity in the future [69-71]. There is growing evidence that both interannual and decadal shifts, either poleward or to deeper water, have caused a redistribution of marine organisms which partly associated with thermal habitat preference and changing temperature [72-76]. When testing the thermal tolerance of B. undatum to examine the possible impact of climate warming on range shift, Smith et al. [19] found that during the early ontogeny, whelk possess thermal resilience to ocean warming; however, it comes at the cost of a reduced number of offspring. Successful development was greatest within their natural developmental temperature range $\left(6-10{ }^{\circ} \mathrm{C}\right)$ but was observed up $18{ }^{\circ} \mathrm{C}$, rates of development increased with temperatures yet the proportion of each egg mass developing successfully decreased [19]. This developmental plasticity with increasing temperature suggests that $B$. undatum may possess thermal flexibility to ocean warming, but this resilience comes with fewer offspring which can negatively impact population size at the southern species distribution, such as the MAB. Should ocean warming continue, $B$. undatum and other cold-water species may be forced to migrate, if possible, seeking deeper and colder waters which are more optimal for physiology [23] which could negatively impact the economic viability of this emerging fishery.

\section{Conclusions}

Given the expansive distribution of B. undatum and its commercial importance, it is critical to fully understand reproductive development in this species. In the 
Mid-Atlantic waters of the U.S. this species is largely unexploited; however, growing interest in developing a commercial fishery lends importance to understanding population dynamics. While reproductive dynamics in this species fluctuate globally, our results suggest early spring as an appropriate time to assess size of sexual maturity in the MAB. Understanding the reproductive cycle and its relationship with bottom water temperature allows forecasting sampling windows and collection of appropriate population data; however, additional studies would allow for an understanding of interannual variability. Moving forward, investigators should focus on $B$. undatum population growth, connectivity, and ecosystem interaction, all of which, are essential to fully understanding this species in the U.S. waters.

\section{Acknowledgements}

We would like to thank all captains and crew members from the vessels who assisted in sample collection, without whom this project would not have been successful: F/V Elise G and F/N Nancy Elizabeth. We are also grateful to the researchers who assisted with sample collection and laboratory work: Joe Caracappa, Sally Roman, Michael Acquafredda, Jenny Paterno Shinn, David Bushek, Iris Burt, Eleanor Bochenek, Jason Morson, Jenn Gius, Emily Scarpa McGurk, and Doug Zemeckis. This manuscript was greatly improved by comments and suggestions from the anonymous reviewers.

\section{Authors' contributions}

This study is part of the Ph.D. of SB, who collected the samples, performed data analyses, interpreted the results, and wrote the manuscript. DM participated in fieldwork, helped with the writing of the manuscript, and supervised SB work during her Ph.D. JHC provided bias-corrected modelling temperature data of bottom water temperatures from the Regional Ocean Modeling System (ROMS) model and offered valuable review of this manuscript. DR hosted SB on sampling trips, assisted with sample collection, and offered valuable review of this manuscript. All authors read and approved the final manuscript.

\section{Funding}

This work was a continuation of a study funded by NOAA SaltonstallKennedy Grant Program [Grant Number: NA14NMF4270050], and was partially supported by NOAA Sea Scallop Research Set Aside [Grant Number: NA16NMF4540043].

\section{Availability of data and materials}

All data generated or analyzed during this study are included in this published article. Datasets are available from the corresponding author on request.

\section{Ethics approval and consent to participate}

All applicable international, national, and/or institutional guidelines for the care and use of animals were followed. This article does not contain any studies with animals which require institutional animal care and use committee (IACUC) review or approval. This article does not contain any studies with human participants performed by any of the authors.

\section{Consent for publication}

Not applicable.

\section{Competing interests}

The authors declare that they have no competing interests.

\section{Author details}

${ }^{1}$ Haskin Shellfish Research Laboratory, Rutgers University, 6959 Miller Ave., Port Norris, NJ 08349, USA. ${ }^{2}$ Virginia Institute of Marine Science, 1375 Greate Rd., Gloucester Point, VA 23062, USA. ${ }^{3}$ Northeast Fisheries Science Center, NOAA, 166 Water St., Woods Hole, MA 02543, USA.
Received: 7 August 2019 Accepted: 20 February 2020

Published online: 02 March 2020

\section{References}

1. Gunnarsson K, Einarsson S. Observations on Whelk Populations (Buccinum undatum L., Mollusca; Gastropoda) in Breidifjordur, Western Iceland. ICES Document CM 1995/K: 20. 1995

2. Hancock D. Whelks. Minist Agric Fish Food, Lab Leafl. 1967; No. 15

3. Gendron L. Determination of the size at sexual maturity of the waved whelk in the Gulf of St. Lawerence as a basis for the establishment of a minimum catchable size. J Shellfish Res. 1992;11:1-7.

4. Santarelli L, Gros P. Détermination de l'âge et de la croissance de Buccinum undatum L. (Gasteropoda: Prosobranchia) à l'aide des isotopes stables de la coquille et de l'ornementation operculaire. Ocean Acta. 1985;8:1-15.

5. Borsetti S, Munroe D, Rudders DB, Dobson C, Bochenek EA. Spatial variation in life history characteristics of waved whelk (Buccinum undatum L.) on the U.S. Mid-Atlantic continental shelf. Fish Res. 2018;198:12937. https://doi.org/10.1016/j.fishres.2017.10.006

6. State of Maine Department of Marine Resources: Whelks. https://www. maine.gov/dmr/science-research/species/whelks.html. Accessed 15 July 2019.

7. Shelmerdine RL, Adamson J, Laurenson CH, Leslie B. Size variation of the common whelk, Buccinum undatum, over large and small spatial scales: potential implications for micro-management within the fishery. Fish Res. 2007:86(2):201-6.

8. Valentinsson D, Sjödin F, Jonsson PR, Nilsson P, Wheatley C. Appraisal of the potential for a future fishery on whelks (Buccinum undatum) in Swedish waters: CPUE and biological aspects. Fish Res. 1999;42(3):215-27.

9. Haig JA, Pantin JR, Salomonsen H, Murray LG, Kaiser MJ. Temporal and spatial variation in size at maturity of the common whelk (Buccinum undatum). ICES J Mar Sci. 2015;72(9):2707-19.

10. Weetman D, Hauser L, Bayes MK, Ellis JR, Shaw PW. Genetic population structure across a range of geographic scales in the commercially exploited marine gastropod Buccinum undatum. Mar Ecol Prog Ser. 2006;317:157-69.

11. Mariani S, Peijnenburg KTCA, Weetman D. Independence of neutral and adaptive divergence in a low dispersal marine mollusc. Mar Ecol Prog Ser. 2012;446:173-87.

12. Magnúsdóttir H, Pálsson $S$, Westfall KM, Jónsson ZO, Örnólfsdóttir EB. Morphological variation in genetically divergent populations of the common whelk, Buccinum undatum (Gastropoda: Buccinidae), across the North Atlantic. Biol J Linn Soc. 2019;128:93-106.

13. Pálsson $\mathrm{S}$, Magnúsdóttir H, Reynisdóttir S, Jónsson ZO, Örnólfsdóttir EB. Divergence and molecular variation in common whelk Buccinum undatum (Gastropoda: Buccinidae) in Iceland: a trans-Atlantic comparison. Biol J Linn Soc. 2014;11:145-59.

14. Hilborn R, Walters CJ. Quantitative fisheries stock assessment: choices, dynamics and uncertainty. New York: Chapman \& Hall; 1992. p. 570.

15. Martel A, Larrivée DH, Himmelman JH. Behaviour and timing of copulation and egg-laying in the neogastropod Buccinum undatum L. J Exp Mar Bio Ecol. 1986;96(1):27-42.

16. Martel A, Larrivée DH, Klein KR, Himmelman JH. Reproductive cycle and seasonal feeding activity of the neogastropod Buccinum undatum. Mar Biol Int J Life Ocean Coast Waters. 1986;92(2):211-21.

17. Kideys AE, Nash RDM, Hartnoll RG. Reproductive cycle and energetic cost of reproduction of the neogastropod Buccinum undatum in the irish sea. J Mar Biol Assoc United Kingdom. 1993;73(2):391-403.

18. Valentinsson D. Reproductive cycle and maternal effects on offspring size and number in the neogastropod Buccinum undatum (L.). Mar Biol. 2002;140(6):1139-47.

19. Smith KE, Thatje S, Hauto A. Thermal tolerance during early ontogeny in the common whelk Buccinum undatum (Linnaeus 1785): bioenergetics, nurse egg partitioning and developmental success. J Sea Res. 2013;79:32-9.

20. Smith KE, Thatje S. Nurse egg consumption and intracapsular development in the common whelk Buccinum undatum (Linnaeus 1758). Helgol Mar Res. 2013;67(1):109-20. 
21. Hollyman P. Age, growth and reproductive assessment of the whelk, Buccinum undatum, in coastal shelf seas. Menai Bridge: Bangor University; 2017

22. Magnúsdóttir H. The common whelk (Buccinum undatum L.): Life history traits and population structure. University of Iceland; 2010.

23. Smith KE, Thatje $\mathrm{S}$. The secret to successful deep-sea invasion: does low temperature hold the key? PLoS ONE. 2012;7(12):30-3.

24. Laptikhovsky $\mathbf{W}$. Does starfish predation determine spawning seasonality in the whelk Buccinum undatum in the Gulf of St Lawrence? J Molluscan Stud. 2014;80(March):219-21.

25. Fahy E, Masterson E, Swords D, Forrest N. A second assessment of the whelk fishery Buccinum undatum in the southwest Irish Sea with particular reference to its history of management by size limit. Mar Institute, Dublin. 2000;52. http://oar.marine.ie/handle/10793/799.

26. Mclntyre R, Lawler A, Masefield R. Size of maturity of the common whelk, Buccinum undatum: is the minimum landing size in England too low? Fish Res. 2015;162:53-7. https://doi.org/10.1016/j.fishres.2014.10.003.

27. Emmerson JA, Haig JA, Bloor ISM, Kaiser MJ. The complexities and challenges of conserving common whelk (Buccinum undatum L) fishery resources: spatio-temporal study of variable population demographics within an environmental context. Fish Res. 2018;204:125-36. https://doi. org/10.1016/j.fishres.2018.02.015.

28. Emmerson JA, Hollyman PR, Bloor ISM, Jenkins SR. Effect of temperature on the growth of the commercially fished common whelk (Buccinum undatum, L.): a regional analysis within the Irish Sea. Fish Res. 2020;223:105437. https://doi.org/10.1016/j.fishres.2019.105437.

29. Castelao R, Glenn S, Schofield O, Chant R, Wilkin J, Kohut J. Seasonal evolution of hydrographic fields in the central Middle Atlantic Bight from glider observations. Geophys Res Lett. 2008;35:L03617.

30. Schofield O, Chant R, Cahill B, Castelao R, Gong D, Kahl A, et al. The decadal view of the Mid-Atlantic Bight from the COOLroom: is our coastal system changing? Oceanography. 2008;21(4):108-17.

31. Bigelow HB. Studies of the Waters of the continental shelf, Cape Cod to Chesapeake Bay 1: the cycle of temperature. Pap Phys Oceanogr Meteorol. 1933;2(4):135.

32. Ketchum BH, Corwin N. The persistence of "winter" water on the continental shelf south of Long Island, New York. Limnol Oceanogr. 1964:9:467-75.

33. Boicourt W, Hacker P. Circulation on the Atlantic continental shelf of the United States, Cape May to Cape Hatteras. Mem la Société R des Sci Liege. 1976;10:187-200.

34. Beardsley RC, Boicourt WC, Hansen DV. Physical oceanography of the Middle Atlantic Bight. Am Soc Limnol Oceanogr Proc Spec Symp. 1976;2:20-34.

35. Beardsley RC, Boicourt WC. On estuarine and continent-shelf circulation in the Middle Atlantic Bight. In: Warren W, editor. Evolution of Physical Oceanogrphy. Cambridge: MIT Press; 1981. p. 198-233.

36. Houghton RW, Schlitz R, Beardsley RC, Butman B, Chamberlin JL. The middle atlantic bight cold pool: evolution of the temperature structure during summer 1979. J Phys Oceanogr. 1982;12:1019-29. https ://doi.org/10.1175/1520-0485\%281982\%29012\%3C1019\%3ATMA BCP\%3E2.0.CO\%3B2.

37. Bignami F, Hopkins TS. Salt and heat trends in the shelf waters of the southern Middle-Atlantic Bight. Cont Shelf Res. 2003;23(6):647-67.

38. Rayner NA, Parker DE, Horton EB, Folland CK, Alexander LV, Rowell DP, et al. Global analyses of sea surface temperature, sea ice, and night marine air temperature since the late nineteenth century. J Geophys Res D. 2003;108:14.

39. Wu L, Cai W, Zhang L, Nakamura H, Timmermann A, Joyce T, et al. Enhanced warming over the global subtropical western boundary currents. Nat Clim Chang. 2012;2(3):161-6.

40. Hobday AJ, Pecl GT. Identification of global marine hotspots: sentinels for change and vanguards for adaptation action. Rev Fish Biol Fish. 2013;24(2):415-25.

41. Gaichas S, Link JS, Hare JA. A risk-based approach to evaluating northeast US fish community vulnerability to climate change. ICES J Mar Sci. 2014;71(8):2323-42.

42. Hare JA, Morrison WE, Nelson MW, Stachura MM, Teeters EJ, Griffis $\mathrm{RB}$, et al. A vulnerability assessment of fish and invertebrates to climate change on the northeast U.S. continental shelf. PLOS ONE. 2016;11(2):1-30.
43. Rudders DB. Virgina Institute of Marine Science dredge survey methods report: Scallop survey methods review. 2015.

44. Roman SA, Rudders DB. Selectivity of Two Commercial Dredges Fished in the Northwest Atlantic Sea Scallop Fishery. J Shellfish Res. 2019;38(3):573.

45. Kang D, Curchitser EN. Gulf Stream eddy characteristics in a high-resolution ocean model. J Geophys Res Ocean. 2013;118(9):4474-87.

46. Chang J-H, Hart D, Curchitser E, Fratatoni P, Munroe D. Bias correction of bottom temperature and salinity predictions from oceanographic models.

47. Lawler A. Determination of the Size of Maturity of the Whelk Buccinum undatum in English Waters. 2014.

48. Brokordt KB, Guderley HE, Guay M, Gaymer CF, Himmelman JH. Sex differences in reproductive investment: maternal care reduces escape response capacity in the whelk Buccinum undatum. J Exp Mar Biol Ecol. 2003;291(2):161-80

49. Roa R, Ernst B, Tapia F. Estimation of size at sexual maturity: an evaluation of analytical and resampling procedures. Fish Bull. 1999;97(3):570-80.

50. Walker TI. Reproduction in fisheries science. In: Hamlett W, editor. Reproductive biology and phylogeny of chondrichthyans: sharks, batoids, and chimaeras. Enfield: Science Publishers, Inc.; 2005. p. 81-127.

51. Tétreault F, Himmelman JH, Measures L. Impact of a castrating trematode, Neophasis sp., on the common whelk, Buccinum undatum, in the Northern Gulf of St. Lawrence. Biol Bull. 2000;198(2):261-71.

52. Harry AV. Maturity ogive R. 2013. https://gist.github.com/alharry/45766 75. Accessed 17 May 2017.

53. Stephenson K. Determination of the Size of Maturity of the Whelk Buccinum undatum within the Devon \&amp; Severn IFCA District. Vol. Research $\mathrm{R}$, Inshore Fisheries and Conservation Authority. Devon \& Severn IFCA District; 2015

54. Køie M. On the endoparasites of Buccinum undatum L. with special reference to the trematodes. Ophelia. 1969;6(1):251-79. https://doi. org/10.1080/00785326.1969.10409652.

55. Crawley MJ. The R Book. Blackwell: Wiley; 2007

56. Ilano AS, Fujinaga K, Nakao S. Reproductive cycle and size at sexual maturity of the commercial whelk Buccinum isaotakii in Funka Bay, Hokkaido, Japan. J Mar Biol Assoc United Kingdom. 2003;83:1287-95.

57. Bolger E. The abundance, movement and population characteristics of common whelk, Buccinum undatum (L.), in an area under consideration for an offshore windfarm development in the territorial waters of the Isle of Man. Bangor University. 2014.

58. Feare C. The reproductive cycle of the dog whelk (Nucella lapillus). Proc Malacol Soc Lond. 1970;39:125-37.

59. Lambert P, Dehnel PA. Seasonal variations in biochemical composition during the reproductive cycle of the intertidal gastropod Thais lamellosa Gmelin (Gastropoda, Prosobranchia). Can J Zool. 1974;52(3):305-18.

60. Stickle B. The reproductive physiology of the intertidal prosobranch Thais lamellosa (Gmelin). II. Seasonal changes in biochemical composition. Biol Bull. 1975;148:448-60.

61. Himmelman JH, Hamel J. Diet, behaviour and reproduction of the whelk Buccinum undatum in the northern Gulf of St. Lawrence, eastern Canada. Mar Biol. 1993;116(3):423-30.

62. Kideys AE. Estimation of the density of Buccinum undatum (Gastropoda) off Douglas, Isle of Man. Helgoländer Meeresuntersuchungennder. 1993;47:35-48.

63. Hancock DA. Marking experiemnts with the commercial whelk (Buccinum undatum). Spec Publ Int Comm Northwest Atl Fish. 1963;4:176-87.

64. Heude-Berthelin C, Hégron-Macé L, Legrand V, Jouaux A, Adeline B, Mathieu $M$, et al. Growth and reproduction of the common whelk Buccinum undatum in west Cotentin (Channel), France. Aquat Living Resour. 2011;24:317-27.

65. McQuinn $1 H$, Gendron L, Himmelman JH. Area of attraction and effective area fished by a whelk (Buccinum undatum) trap under variable conditions. Can J Fish Aquat Sci. 1988;45:2054-60.

66. Himmelman JH. Movement of whelks (Buccinum undatum) towards a baited trap. Mar Biol. 1988;97(4):521-31.

67. Fretter $\vee$, Graham A. The prosobranch molluscs of Britain and Denmark. Part 8 Neogastropoda. J Molluscan Stud Suppl. 1984;15:435-556.

68. Pershing AJ, Alexander MA, Hernandez CM, Kerr LA, le Bris A, Mills KE, et al. Slow adaptation in the face of rapid warming leads to collapse of the Gulf of Maine cod fishery. Science. 2015;350:809-12. 
69. Planque B, Frédou T. Temperature and the recruitment of Atlantic cod (Gadus morhua). Can J Fish Aquat Sci. 1999;56(11):2069-77. https://doi. org/10.1139/f99-114.

70. Drinkwater KF. The response of Atlantic cod (Gadus morhua) to future climate change. ICES J Mar Sci. 2005;62(7):1327-37.

71. Forgarty M. Potential climate change impacts on Atlantic cod (Gadus morhua) off the northeastern USA. Mitig Adapt Strateg Glob Chang. 2008;13(5-6):453-66.

72. Weinberg JR. Bathymetric shift in the distribution of Atlantic surfclams: response to warmer ocean temperature. ICES J Mar Sci. 2005;62(7):1444-53.

73. Lucey SM, Nye JA. Shifting species assemblages in the Northeast US Continental Shelf Large Marine Ecosystem. Mar Ecol Prog Ser. 2010;415:23-33.

74. Nye JA, Link JS, Hare JA, Overholtz WJ. Changing spatial distribution of fish stocks in relation to climate and population size on the Northeast United States continental shelf. Mar Ecol Prog Ser. 2009:393:111-29.

75. Sunday JM, Bates $A E$, Dulvy NK. Thermal tolerance and the global redistribution of animals. Nat Clim Chang. 2012;2(9):686-90. https://doi. org/10.1038/nclimate1539.

76. Poloczanska ES, Brown CJ, Sydeman WJ, Kiessling W, Schoeman DS, Moore PJ, et al. Global imprint of climate change on marine life. Nat Clim Chang. 2013;3(10):919-25.
77. Moore H. Marine fauna of the Isle of Man. Proc Trans Liverpool Biol Soc. 1937;50:1-293.

78. Kristensen $\mathrm{E}$. The coastal waters of the Netherlands as an environment of molluscan life. Basteria. 1959;23:18-46.

79. Kuznetsov V. Seasonal and temperature conditions for the breeding of marine invertebrates. In: Palenichko Z, editor. Data for a comprehensive study of the White Sea, vol. 2. Moscow: Akademii Nauk SSSR; 1963. p. 32-52.

80. Aurivullius C. Om Hafsevertebraternas Utvecklingstider och Periodiciteten i Larvformernas Uppträdande vid Sveriges Vestkust. Bih Till K Sven Vetenskaps-Akademiens Handl Afd. 1898;4(4):1-91.

81. Cunningham J. Formation of egg-capsules in Gasteropoda. Nature. 1899;59:557.

82. Lebour M. The eggs and larvae of the British prosobranchs with special reference to those living in the plankton. J Mar Biol Assoc UK. 1937;22:105.

\section{Publisher's Note}

Springer Nature remains neutral with regard to jurisdictional claims in published maps and institutional affiliations.
Ready to submit your research? Choose BMC and benefit from:

- fast, convenient online submission

- thorough peer review by experienced researchers in your field

- rapid publication on acceptance

- support for research data, including large and complex data types

- gold Open Access which fosters wider collaboration and increased citations

- maximum visibility for your research: over $100 \mathrm{M}$ website views per year

At BMC, research is always in progress.

Learn more biomedcentral.com/submissions 